UDC 339.94:[339.5:339.137.2]

DOI 10.33111/iep.2019.31.03_eng

\title{
Global Economic Networkization in the Competitive Growth of Countries
}

\section{LARYSA ANTONIUK, NATALita ChERKas ${ }^{1}$}

\begin{abstract}
The article identifies the main determinants of the global competitiveness of countries in the context of production networkization. The economic dimension of the participation of countries in global value chains is analyzed and the effectiveness of internationalization and integration of subjects of international economic relations to global production networks and value chains based on forward over backward participation indicators is assessed. There was carried out the assessment of the creation of added value of products in global networks in the context of fragmentation of production, which allowed to determine the path of transition of the economy into a globally integrated sphere of services and production of products with a high share of added value. The influence of the business environment on the goods production with a high share of added value and international competitiveness based on the analysis of panel data in European countries is determined. It is proved that a high share of value added depends on the budget balance improvement, the quality of human capital, the transparency of the work of state institutions and the moderate strengthening of the monetary unit; technological transfer occurs primarily through the import of technology; European integration increases the non-price competitiveness of the countries of Central and Eastern Europe in the global market for high-tech products. It has been proved that a significant factor of the companies' global competitiveness increase is expansion of their presence in international value chains, as well as fiscal discipline, research and development costs increase, investments in the development of human capital, share of domestic value added increase and services sector development. The imperative of production modernization in the context of global value chains is revealed and conceptual provisions are identified for overcoming the "middle-income level trap" that arises as a result of a slowdown in the involvement of technological industries in conditions of insufficient absorption capacity. The strategic priorities of the policy of countries integration into global production networks, which provide for joining global value chains, are justified; expansion and strengthening of our own positions and obtaining of the maximum benefits from this participation, taking into account the balanced development of the country. The competitive potential of the national economy and the degree of its implementation in global value chains are assessed. The strategic directions of the international competitive position of Ukraine's economy increase in the context of global networkization have been substantiated. The influence of the business environment on Ukrainian economy competitiveness increase is investigated and the importance of technological exports as a factor of strengthening of the monetary unit and wages increase is proved, while it also allows to develop the technological sectors.
\end{abstract}

* This article was translated from its original in Ukrainian.

1 Antoniuk Larysa Leontiivna - Doctor of Economics, Professor, Vice-Rector for Scientific Research at Kyiv National Economic University named after Vadym Hetman". Sphere of scientific interest: competitiveness of national economy, venture capital, university education, socio-economic entrepreneurship.E-mail: antoniuk@kneu.edu.ua

Cherkas Nataliia Ihorivna - Doctor of Economics, Associate Professor, Senior Researcher at the Institute of Economic Development Studies, Kyiv National Economic University named after Vadym Hetman. Sphere of scientific interest: international competitiveness, global value chains, global production networks, structural shifts in foreign trade. E-mail: cherkas@kneu.edu.ua

IEP, № 31, (2019) pp. 82-100

(C) Larysa Antoniuk, Nataliia Cherkas, 2019 «All rights reserved»

ISSN 1811-9832/2019/№ 2 (31) 
KEY WORDS: global networkization, global competitiveness, global value chains, global production networks, value added, fragmentation of production, business environment, foreign trade patterns.

\section{Introduction}

Recent decades are characterized by a qualitative transformation and diversification of international business activity institutional forms, which is primarily expressed in the relocation of production sites of transnational corporations and their integration into production networks and value chains in order to ensure global competitive leadership. These changed are clearly showed in the process of global reproduction of a social product - from changes in structural parameters and geographical fragmentation of production with increasing volume of foreign investment, international distribution and consumption of goods and services produced to automation and digitalization of production and logistics operations with the implementation of decentralized network management systems. As a result, the landscape of the global economy is changing, and the global production networks and value chains are transformed into a financial and technological core and a generator of dynamic movement of goods, services, investments, and innovations. The concentration of these strategic resources in the transnational corporations' divisions is the main factor of TNC global competitive leadership in all segments of the global market, with the formation of the dynamic competitive benefits of the national economies of the home countries of their parent companies.

Increasing of the international competitive ability of countries provides the development of national economic strategies, taking into account the sectoral involvement of business entities in global value chains and their functional integration ${ }^{2}$. The technological breakthroughs of 4.0 Industry, the digital transformation of business processes and models, the deepening of specialization and regional business operations reshoring, geographical consolidation and concentration of transnational distribution networks in cooperation with small and medium-sized enterprises in competition mode and relevant corporate control are key factors to achieve this strategic goal ${ }^{3}$.

A better understanding of the essence and philosophy of the development of global production networks makes it possible to carry out a comprehensive assessment of trade imbalances, directions of

\footnotetext{
${ }^{2}$ Baldwin R. The Great Convergence // Harvard University Press. - 2016. - 329 p.

3 1. Cherkas N.I. Transformational Impact of the Industry 4.0 on Global Production Networks and Value Chains (ukr. Transformatsiinyi vplyv Industrii 4.0 na hlobalni merezhi vyrobnytstva ta lantsiuhy vartosti) // Economics of Industry (Ekonomika promyslovosti). — 2018. — No. 1(81). — pp. 5-20.
} 
capital flows, changes in the exchange rate and reasons of ways to optimize micro- and macro-strategies of internationalization ${ }^{4}$. In this context, the integration of Ukraine into global value chains with efficient use of internal potential is a necessary condition for its innovation and investment development. Significant contribution to the development of concepts of global value chains in the context of increasing international competitiveness of countries was made in theoretical and empirical works R. Baldvin, M. Blanchet, J. Humphrey, M. Granovetter, P. Dicken, G. Jereffy, R. Kaplinski, O. Katanello, F. Kimura, O. Kontreras, P. Kruhman, J. Manyika, D. Messner, M. Porter, V. Rostow, T. Stardzheon, D. Taglioni, M. Hess, E. Helpman, T. Hopkins, D. Humels, I. Burakovskyi, A. Halchynskyi, V. Geiets, I. Guzhva, K. Zhylenko, D. Ilnytskyi, D. Lukianenko, T. Melnyk, T. Oriekhova, A. Poruchnyk, O. Rohach, Ya. Stolyarchuk, T. Tsyhankova, I. Chuzhykov, O. Shvydanenko, V. Shevchuk. However, the effectiveness assessment problems of of the integration of countries into the global networks and value chains remain insufficiently disclosed in foreign and domestic literature. Mechanisms of the national economy competitive potential growth for the integration into global value chains, based on the trajectory of technological complexity, taking into account existing competitive advantages, require comprehensive analysis. Furthermore, empirical studies of the business environment influence on the formation of export competitiveness in the context of production fragmentation in the global networks remain very urgent.

The purpose of the article is a comprehensive research of the directions, forms and mechanisms of their effective involvement of international economic relations subjects in global value chains and production networks and substantiation of strategic priorities of increasing the competitiveness of the Ukrainian economy.

\section{Theoretical foundations for global production networks and value chains research}

The acceleration of globalization and associated dynamic flows of capital, goods, services, material, informational and intellectual resources are a feature of world economy modern development. The dissemination of internationalization and fragmentation production since the middle of 1970s has led to the formation of global networks and value chains, that cover a complex of transnational manufacturing and intermediation

\footnotetext{
4 Cingolani I., Iapadre L., Tajoli L. International production networks and the world trade structure // International Economics. — 2018. - No. 153. - pp. 11-33.
} 
operations for goods production and service provision ${ }^{5}$. The scientific understanding of this area comes from the classical and neoclassical theories of international trade, international competitiveness concept, and is based on previous research of global trade chains in trans-border production networks and models of developed countries industrial reorganization ${ }^{6}$. We have made the conceptualization of global economic networking as a process of coordinated interaction of companies in value chains on the basis of international division of labor and their functional specialization at different levels of goods technological production processes and $\mathrm{f}$ services provision in order to increase their international competitiveness.

There is conducting the coordination of global production, trade and investment as a result of manufacturing processes fragmentation into countries/regions with dynamic comparative advantages in the global value chains and production networks ${ }^{7}$. The analysis determinant of balanced economic growth confirmed that global value chains are an imperative for the countries' export competitiveness increase and formation of their highly competitive status. There is a significant increase in the part of intermediate goods trade in recent decades (the import component of exports was $20 \%$ in $1990,51 \%$ in 2018 , and in 2030 it will be $60 \%)^{8}$. Since 2009 , there was paid specific attention to the strategies of international organizations development such as the World Bank, World Trade Organization, UNCTAD, UNIDO, InterAmerican Development Bank, Asian Development Bank and others in the research of global value chains ${ }^{9}$.

The function of global value chains and production networks occurs in the environment of institutions and supporting sectors with the inclusion of critical resources complex (human capital assets, infrastructure, capital investment, services and others) (Fig. 1).

The structure of global value chain management forms a hierarchy of participants and a way of attraction of financial, material resources and human capital in a system of relationships between transnational business entities that contains market, modular, relative, closed and hierarchical types of management ${ }^{10}$. Based on the theory of international division of

${ }^{5}$ Global Value Chain Development Report // International Bank for Reconstruction and Development. The World Bank. -2017 . $-190 \mathrm{p}$.

${ }^{6}$ Hernández V., Pedersen T. Global value chain configuration: A review and research agenda // Business Research Quarterly. - 2017. - No. 20(2). - pp. 137-150.

${ }^{7}$ Horner R., Nadvi K. Global value chains and the rise of the Global South: unpacking twenty-first century polycentric trade // Global Networks. - 2018. - No. 18(2). - pp. 207-237.

${ }^{8}$ WIOD, World Input-Output Database. http://www.wiod.org

${ }^{9}$ Johnson R.C., Noguera G. A Portrait of Trade in Value-Added over Four Decades // Review of Economics and Statistics. - 2017. - No. 99(5). - pp. 896-911.

${ }_{10}$ Global Value Chain Development Report // International Bank for Reconstruction and Development. The World Bank. -2017 . $-190 \mathrm{p}$. 
labor and generalization of reports and analytical publications of WOT and $\mathrm{OECD}^{11}$ there is determined that the concept of global production networks as the highest level of value chains organization consists of interdependent economic and non-economic entities, coordinated by a leading company in transnational business activities for global markets; they compete and collaborate to form, transform and manage value added. Three interconnected conceptual categories are key in WAN 1.0 theory: value added, embeddedness and management hierarchy that determine the dynamics of territories economic development ${ }^{12}$. The 2.0 theory of global production networks concerns the structural competitive dynamics and strategies of network organization (internal coordination, control, partnership and exchange between companies) ${ }^{13}$.

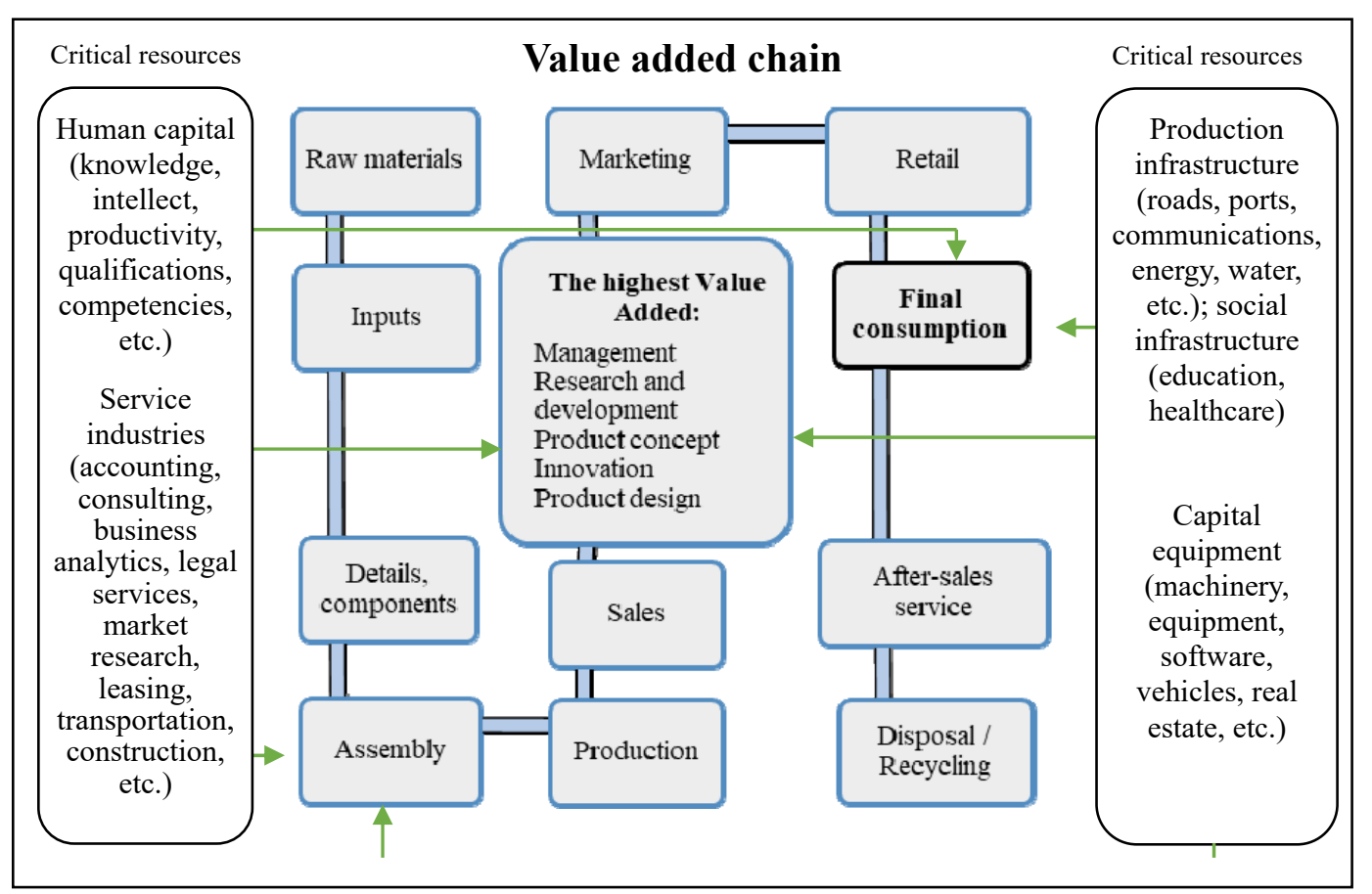

Fig. 1. The components of the production chain of value added

Source: compiled by the author

\footnotetext{
${ }^{11}$ OECD - WTO Trade in Value-Added (TiVA) initiative. http://www.oecd.org/sti/ind/measuringtradeinvalueaddedanoecd-wtojointinitiative.htm.

12 Dicken P., Kelly P.F., Olds K., Wai-Chung Yeung H. Chains and networks, territories and scales: towards a relational framework for analysing the global economy // Global networks. - 2001. — No. 1(2). - pp. 89-112.

13 Coe N.M., Yeung H.W.C. Global production networks: Theorizing economic development in an interconnected world // Oxford University Press. -2015 . -266 p.
} 
In the context of global value chains functioning, there is a difference between the cross-border gross flows of goods and services (imports/exports) and the formation of real value added in the country. Exports of final products are consumed in the country of consignment, as opposed to intermediate goods. Remarkably, that the differences between final and intermediate products are difficult to trace from official statistical sources, because the final consumption is not recorded in customs statistics ${ }^{14}$. The bulk of world commerce of intermediate goods is organized around three powerful regional clusters - East Asia, centered in China; Europe, dominated by supply chains of German companies; and North America focused on the United States of America (Fig. 2).

Consequently, most developing countries are on the periphery of the processes of global economic networkization. The countries of the center ensure the transfer of knowledge and know-how only within their production networks and value chains and control their storage; it represents significant challenges for countries specializing in raw materials, low-tech and assembly industries. At the same time, there is existed a high concentration in the international flows of goods, services, capital and labor within a small group of leading countries (15 countries - world exporters own $63 \%$ of total exports; $62 \%$ of service trades and $79 \%$ of global foreign direct investment $)^{15}$. Participation in global networks is a dominant factor in the growth of TNC income, since sales of intermediate products through the supply chain provide about $50 \%$ of global corporate income.

Global Economic Crisis of 2008-2009 caused a noticeable slowdown in world trade dynamics: over the past decade, global GDP and export growth rates were $2.4 \%$ and $1.4 \%{ }^{16}$. Global networkization was a significant reason for the slowdown in world trade, since the expansion of global value chains had stabilized before the crisis began and it limited the flexibility of trade due to the increased specialization, modular production, reshoring, and a focus on regional production networks.

\footnotetext{
14 Nielsen P.B. The puzzle of measuring global value chains - The business statistics perspective // International Economics. - 2018. - No. 153. - pp. 69-79.

${ }_{15}$ West J. Getting Better Value Out of Global Value Chains // In Asian Century... on a Knife-edge. Palgrave Macmillan, Singapore. - 2018. - pp. 91-123.

${ }^{16}$ UNCTAD Statistics Data Centre. "International trade”. URL: http://unctadstat.unctad.org.
} 


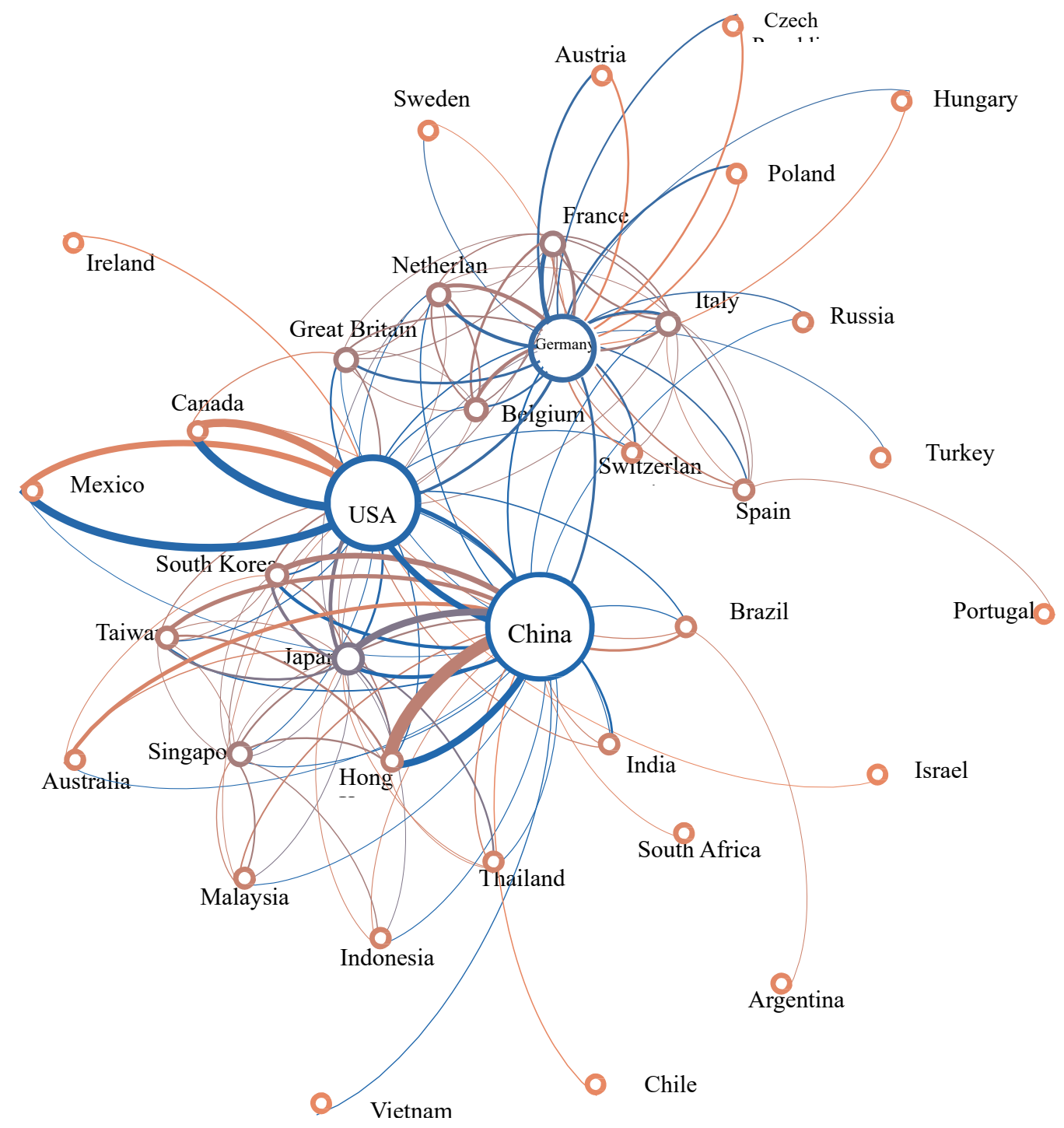

Fig. 2. Bilateral flows of the main entities of the Global Trade Network of Intermediate Products, 2017

Source: developed by the authors based on: UNCTAD Statistics Data, Global Value Chain Development Report 2017

Estimation of value-added trade involves the decomposition of total exports from the allocation of internal and external components of value added based on the participation index in global value chains (GVCs 
participation index), consisting of forward participation and backward participation $^{17}$. A holistic analysis of participation indicators in global value chains of the leading economies of the world made it possible to determine that a high share of domestic value added in exports is characteristic of economies with high GDP per capita and/or exporting countries of raw materials (more than 70\%) (Fig. 3). The share of external value added in the export of EU countries was about $30 \%$ in 2018 (Norway - 17\%, Germany - 25\%, Hungary - 49\%).

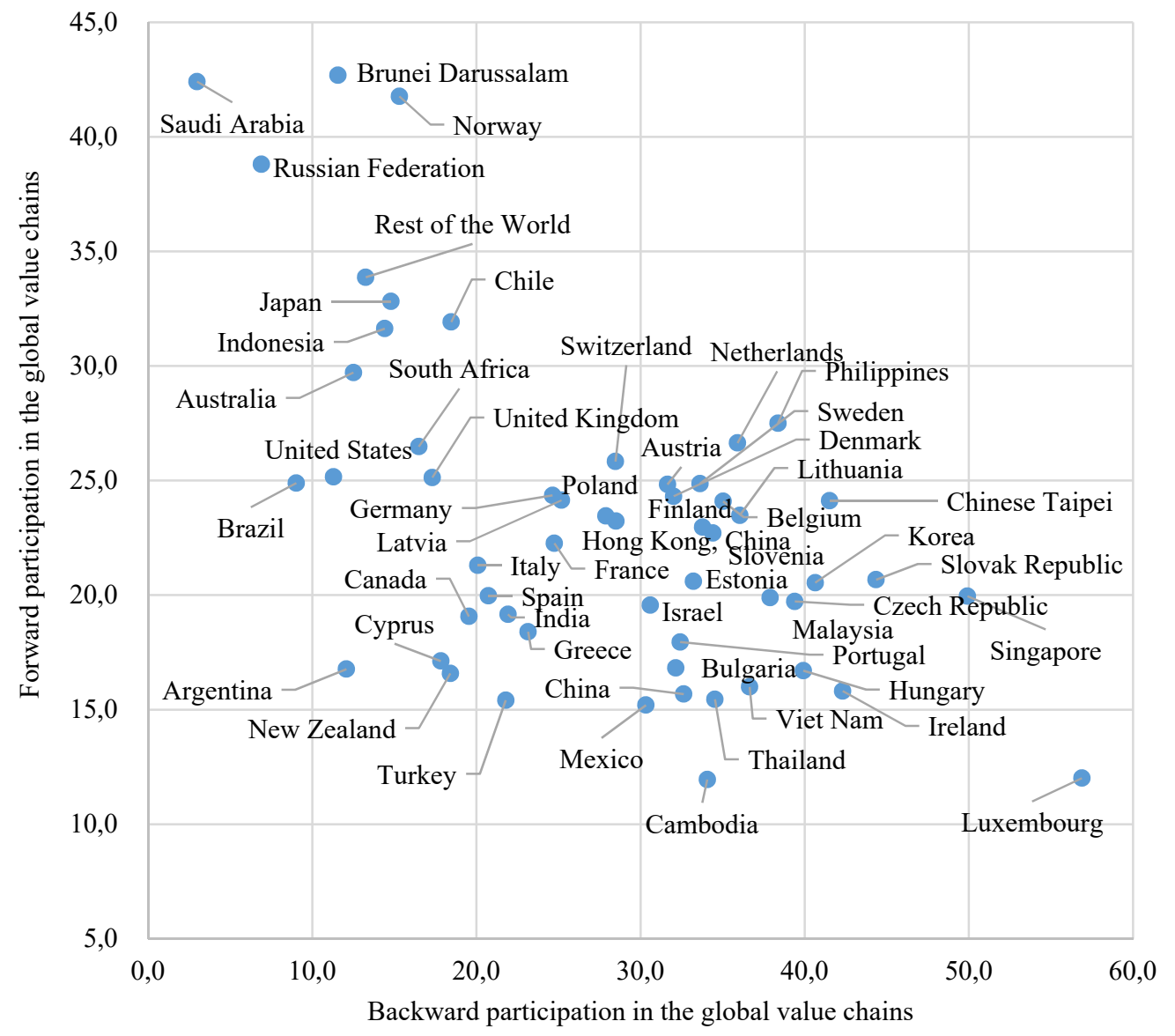

Fig. 3. Forward and backward participation in the global value chains, 2018.

Source: developed by the authors based on OECD - WTO Trade in Value-Added database

\footnotetext{
${ }^{17}$ Koopman R., Wang Z., Wei S.J. Tracing value-added and double counting in gross exports // The American Economic Review. - 2014. -No. 104(2). - pp. 459-494.
} 
Global value chains are largely dependent on the service sector (communication, transport and logistics, information, financial, etc.), which account for more than $65 \%$ of GDP in most high-income countries, and at the same time less than 25\% of exports, since a significant part of service is not foreign trade goods ${ }^{18}$. About $50 \%$ of all global value added is generated in five countries (USA, China, Japan, Germany and France), and they remain as centers of concentration of transnational capital.

The distribution of added value creation in global chains represents a parabolic dependence ("smiling curve"), which provides that less value added is created during the production or packaging of a product than at the initial (research, innovation, design) or final stages (logistics, marketing, post-sale service $)^{19}$. Based on the analysis of TNCs value chains, it was determined that effective participation in the processes of global merchandising depends on the development of tasks from the higher segments of value chains and the transition to a globally integrated services sector. In the host countries, the investment strategies of TNCs are based on gaining access to raw materials, sales markets and transaction costs optimization, that threatens to remain executors of low-value-added operations. Remarkably the share of world exports of final products of high-tech electronic equipment in China increased from 3.4\% in 1995 to $38.9 \%$ in 2018, and imports of intermediate technological products increased from $3 \%$ to $20.1 \%$, and China owns only $18 \%$ of the domestic value added of exports of high-tech products, since the production network is often coordinated by foreign companies.

Based on a study of the global value chain of a technology corporation as example of Apple Inc., in the production of smartphones, it was determined that the global network of its suppliers amounted to 287 of major firms and 770 of their branches at the beginning of 2019, about $60 \%$ of which are located in China ${ }^{21}$. At the same time, the lion's share of raw materials, materials and components is concentrated in the eastern region, and it reduces logistics and transportation costs. It is worth pointing out that, that in the structure of the cost of iPhone production, the share of remuneration of workers engaged in final assembly is $2 \%$, the cost of materials is $22 \%$, the profitability of the corporation is $58 \%$. The negative bilateral balance of the USA and China in 2018 amounted to $46.1 \%$ of the total USA trade balance (USD 398.130 billion), however, based on the assessment of value-added flows in the smartphone trade, it was studied

\footnotetext{
18 Ernst D., Center E.W. Beyond Value Capture-Exploring Innovation Gains from Global Networks // Megaregionalism 2.0: Trade and Innovation Within Global Networks. -2018 . - No. 67. - 55 p.

19 Global Value Chain Development Report // International Bank for Reconstruction and Development. The World Bank. -2017 . - $190 \mathrm{p}$.

${ }_{20}$ UNCTAD Statistics Data Centre. "International trade". http://unctadstat.unctad.org.

${ }^{21}$ Apple's Supplier Responsibility. https://www.apple.com/supplier-responsibility.
} 
that its main share is generated in the USA, and the favorable balance is occurred with China (USD 3.32 billion) ${ }^{22}$. Accordingly, the reduction of trade barriers contributes to economic growth due to increased competition in the domestic market.

The rapid development of information technology has significantly improved the process of production management, optimized and automated its individual links, as well as increased the effectiveness of quality control. The introduction of technologies that can radically transform business models, such as nanotechnology, additive (3D printing), robotics, and other innovations, causes a significant reformatting of the structure of the global economy and global value chains and leads to their reduction as a result of reshoring. As the value added in the industry of the EU countries decreased from $22 \%$ to $15 \%$ in 1990-2018, the European Commission fixed a target to increase the share of industrial production in GDP to $20 \%$ by $2022^{23}$. Successful implementation of Industry 4.0 initiatives eliminates differences in labor costs between countries, facilitates the placement of units production along with the main consumers and the development of customized production, and expands the possibilities for the reindustrialization of European countries.

\section{An effective business environment in value added and international competitiveness development}

The rapid development of information technology and logistics has significantly accelerated the pace of globalization, simplified the exchange of information and reduced the importance of geographical distances between countries as a factor in economic activity. During the last decade, the spread of global value chains has played an increasingly important role in business strategies shaping, transformed the structure of international trade and affected policies aimed at the economic development of many countries ${ }^{24}$. In the context of Ukraine's current economic situation and attempting to reform it, the experience of using of the macroeconomic policy instruments of the new EU member states and comparison of the corresponding relationships among European countries is extremely important ${ }^{25}$. This led to the feasibility of an empirical analysis of panel data to study the impact of a number of macroeconomic indicators (exchange rate $-E_{i t}$, budget balance $-B B_{i t}$,

\footnotetext{
${ }^{22}$ WIOD, World Input-Output Database. http://www.wiod.org.

${ }^{23}$ Ceglowski J. Assessing export competitiveness through the lens of value added // The World Economy. 2017. - No. 40(2). - pp. 275-296.

${ }_{24}$ Antoniuk L., Cherkas N. Macro level analysis of factors contributing to value added: technological changes in European countries // Problems and Perspectives in Management. - 2018. — No. 16(4). - pp. 417-428.

${ }_{25}$ Cherkas N.I. Exchange Rate and Imports' Impact on Ukraine's Export Structure Dynamics (ukr. Vplyv obminnoho kursu ta importu na dynamiku struktury eksportu Ukrainy) // Economics and Forecasting (Ekonomika $i$ prohnozuvannia). — 2013. - No. 2. - pp. 128-139.
} 
foreign direct investment $-F D I_{i t}$, high-tech import $-M_{-} h t_{i t}$, intraindustry trade $-I I T \_h t_{i t}$, quality of human capital $-H C_{i t}$, corruption perception index $-\overline{C o} r_{-} P I_{i t}$, public debt $-D e b t_{i t}$, GDP growth rate GDP $g_{i t}$ and crisis phenomena - Crisis $\left.s_{i t}\right)$ for value added $\left(V A_{i t}\right)$ and competitiveness in European countries. The sample contains annual data from 27 European countries for the period of 2006-2018, which, considering the geographical heterogeneity of the EU countries, was clustered into three groups: developed economies, GIISP countries (Greece, Italy, Ireland, Spain and Portugal) and CEE countries. STATA.14 statistical program was used. The study was conducted using the ordinary least squares method (OLS), panel data with fixed effects (FE), random effects ( $\mathrm{RE}$ ) and a dynamic panel data (DPD). An analysis of descriptive statistics, an assessment of the quality of models, a logarithmic transformation, testing of causality, and regression analysis are performed. The main determinants of value added for the total sample include: strengthening of the monetary unit, budget deficit reduction, high-tech products import, the quality of human capital, corruption reduction and GDP growth (equation 1) ${ }^{26}$. It has been established that a policy of competitiveness increasing by depreciating of a monetary unit is ineffective in view of the fact that the main advantages are received by consumers or producers of final products.

$$
\begin{aligned}
& V A_{i t}=\begin{array}{cccccc}
-1,211 & +0,516 E_{i t} & +0,199 B B_{i t} & -0,002 F D I_{i t} & +0,586 M_{-} h t_{i t} & -0,128 I I T T_{*} h t_{i t} \\
\left(-2,52^{* *}\right) & \left(9,88^{* *}\right) & \left(2,14^{* *}\right) & (-1,15) & \left(18,99^{* *}\right) & \left(-2,21^{* *}\right)
\end{array}
\end{aligned}
$$

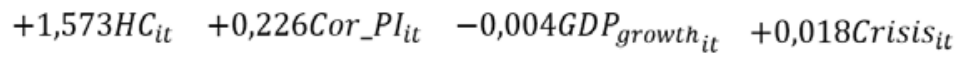

$$
\begin{aligned}
& \left(4,97^{* * *}\right) \quad\left(3,78^{* * *}\right) \quad\left(2,17^{* *}\right) \quad(1,46) \\
& R^{2}=0,612 \quad \text { Hausman }\left(\chi^{2}\right)=143,00 \quad \text { Breusch-Pagan }\left(\chi^{2}\right)=250,54 \\
& \text { F test }=35,09 \quad \text { Prob }>\chi^{2}=0,000 \quad \text { Prob }>\chi^{2}=0,000
\end{aligned}
$$

The results of the analysis for CEE countries and developed economies coincide with the results for the general sample, but do not confirm the relationship with high-tech imports. Competitiveness factors for the overall sample are: increase in value added, devaluation of the monetary unit, decrease in budget deficit, quality of human capital, decrease in corruption and GDP growth. For a subgroup of CEE countries, there was no significant effect of the exchange rate and value added on international competitiveness, however, a positive effect was obtained from added value in industry (the leading export sector in CEE countries). Thus, the results of an empirical study confirm that in order to stimulate the growth of added value, economic regulation

\footnotetext{
$26 * * *, * *$ and * - level of statistical significance 1,5 and 10 per cent respectively. t-statistics is given in parentheses. Calculated by the author based on data from World Bank; WEF; WIOD; UnctadStat; The Lisbon Council; Transparency International.
} 
should focus on balanced budget, development of human capital, stable currency maintenance and eliminating of corruption.

\section{Global value chains in the competitive growth of countries}

The key factors in the economic development of countries include modernization of industry; that occurs at the level of production processes (efficiency and productivity increase) of goods/services (transition to the production of technologically complex products in existing value chains); functional (an increase in the share of value added as a result of orientation toward the performance of complex tasks) and intersectoral (transition to the new value chains with a high level of manufacturability) $)^{27}$.

It is advisable to consider the dynamics of competitiveness of the EU countries in the coordinates of relations between the center and the periphery, under such circumstances the nature of trade and investment flows is determined by considerations of minimizing costs and maximizing added value by taking advantage of diversified networks: upstream networks (extraction of raw materials, supply, production, logistics) and "downstream" (sales, marketing, service). The activities of the ascending sectors are moving to the countries of Eastern Europe, while the downstream sectors remain in the EU-15 countries, and intermediate products from Eastern Europe are used for production in the countries of Central Europe. German labor market reforms since the early 2000s (SME grants getting to start a new business, stimulating the search of jobs for the unemployed, practice of a social pact between trade unions and employers' organizations and the dual education system) significantly increased the efficiency of the economy, contributed to the growth of the share of upstream sectors and the regionalization of low-tech industry in the export sector (off-shoring).

Slowing the pace of technological production attracting to CEE countries leads to the emergence of a "middle-income trap", which is a consequence of increase of real wages in industry in urban localizations, depleting productivity growth, declining international competitiveness and slowing GDP growth. The main obstacle to the transition of countries and regions to a higher income level is the low absorption capacity, in particular, due to insufficient qualifications of workers, poor development of institutions, infrastructure and an unfavorable business environment ${ }^{28}$. In our opinion, the ways to overcome the

${ }^{27}$ Frohm E., Gunnella V. Sectoral interlinkages in global value chains: spillovers and network effects // ECB Working Paper. - 2017. - No. 2064. - 38 p.

${ }_{28}$ Riaz M.F., Cherkas N., Leitão J. Corruption and Innovation: Mixed Evidences on bidirectional Causality // Journal of Applied Economic Sciences. — 2018. — Vol. XIII, Issue 2(56). — pp. 378-384. 
"middle-income level trap" include: infrastructure development; cost reduction for the implementation of production activities; increase in wages in accordance with the growth of labor productivity; to avoid avoidance of the exchange rate; establishment of a dynamic innovative small and medium-sized business; reorientation of the system of higher and secondary education to technical specialties.

The article analyzes the relationships between the indicator of participation of national companies in value chains (latitude index of value chains ${ }^{29}$, scale from 0 to 7 , high positions in 2017 - Switzerland (5.8), Sweden (5.7), Great Britain (5.7) the lowest are Romania (3.6), Ukraine (3.5), Hungary (3.4) and national income for European countries (Fig. 4). According to the results, the growth of national income is positively influenced by the active involvement of countries in global value chains, depending on the level of complementarity of industrial sectors and the development of intra-industry trade.

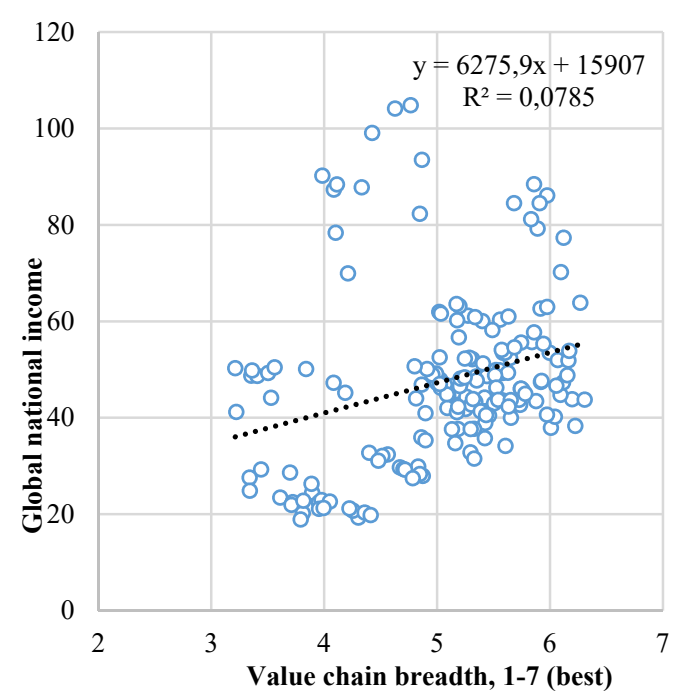

European countries (28)

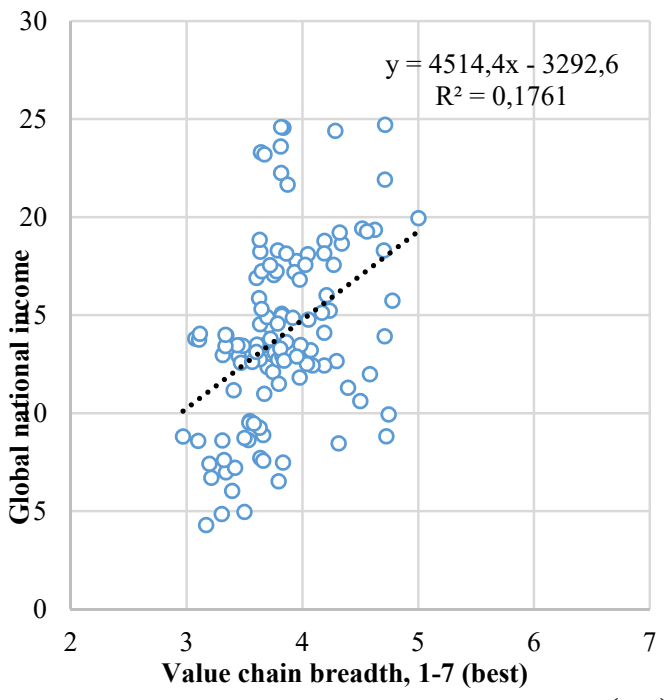

Central and Eastern European countries (12)

Fig. 4. Relationship between value chain breadth and gross national income, 2006-2016.

Source: calculated according to WEF; World bank

${ }^{29}$ The indicator characterizing the concentration of national companies along the value chain (value chain latitude index) is included in the World Economic Forum database as a component for calculating the Global Competitiveness Index (in the $11^{\text {th }}$ sub-index - business complexity). Value chain width index (its value can range from 1 to 7) is formed according to the results of a specialized survey of the degree of participation of companies in the country in the global chains $(1=$ low participation, primarily associated with particular stages, such as production or simple natural resources processing; $7=$ high participation - presence throughout the value chain, such as manufacturing, marketing, management, research, etc.) (author's note). 
The influence of global value chains on domestic economy is carried out through the transmission channels of economic and social modernization: reverse and forward links; out-competitive market restructuring; technology transfer; the minimum scale and labor market effects, including the demand for skilled workers and an increase of their level of knowledge and competencies. Feedback creates a demand effect (high quality standards in leading companies) and a support effect (technology exchange, advance payments, etc.). Technology transfer increases the productivity of national companies through the effects of diffusion (dissemination of knowledge in the sector through suppliers), quality and accessibility (competition in the market for resources and intermediate products) ${ }^{30}$.

For developing countries, expanding participation in global value chains is a priority because it allows to integrate effectively into the global economic system, to attract investment, increase production and improve the dynamics of social and economic development ${ }^{31}$. The implementation of this direction involves joining of global value chains; expansion and strengthening of own positions and getting the maximum benefits from this participation, taking into account the balanced development of countries ${ }^{32}$. To this effect, the government and business will have to take a number of steps: to identify sectors with a high level of competitive advantage; to analyze the positioning of export goods/services in a wide network of intersectoral production relations; to identify the tasks that create the greatest internal added value or that are prospective for economic growth and sustainable development. In order to expand and strengthen the position of companies in global chains, it is necessary to move to the production of goods with a higher level of adaptability in the existing value chain (product modernization), increasing the share of value added in the final product in existing tasks (functional upgrade); and the transition to new global value-added chains (cross-sectoral upgrades). It is advisable to implement investments in human capital through practical knowledge (cooperation of enterprises with universities in commercializing projects, stimulating startups, innovative business models) promoting social modernization (ensuring the mobility of workers, raising standards and quality of life, improving the level of social protection); ensuring a fair distribution of opportunities and results (access to education and creation of conditions for high social mobility).

\footnotetext{
${ }^{30}$ Hernández V., Pedersen T. Global value chain configuration: A review and research agenda // Business Research Ouarterlv. - 2017. - No. 20(2). — pp. 137-150

31 Shevchuk, V., Atamanchuk, Z., Cherkas, N. Balance of Payments and Remonetization Monetary Effects on the Ukrainian Economy (ukr. Monetarni efekty platizhnoho balansu i remonetyzatsiia ukrainskoi ekonomiky) // Strategic Priorities (Stratehichni priorytety). - 2007. -No. 3. - pp. 67-75.

${ }^{32}$ West J. Getting Better Value Out of Global Value Chains // In Asian Century... on a Knife-edge. Palgrave Macmillan, Singapore. — 2018. - pp. 91-123.
} 


\section{Global networkization in economic growth and competitiveness of the economy of Ukraine}

Support of the efforts of national companies to move up global chains in the direction of positions with the highest share of added value should be an important task of the Ukrainian government. Taking into account an experience of EU countries in supporting of less developed regions using the principles of smart specialization, it is advisable for the government to determine the multiplier effects in terms of added value from the possible modernization of the largest Ukrainian companies. In particular, agricultural holdings should be encouraged to export products with high quality characteristics in the direction of high price segments development, for example, organic products will lay the groundwork for the gradual establishment of high-tech sectors (in particular, nutraceuticals and biopharmaceuticals). In Ukraine, only a small part of domestic companies controls their own value chains and/or integrates with international production networks with national technologies, innovations and brands. Mostly, offshoring of production and services for the domestic market takes place, and production processes remain within the control of an international company, which expands the global value chain. In the Ukrainian context, low wages and the relative availability of skilled labor create competitive advantages ${ }^{33}$, but often these factors are offset by administrative obstacles and the weakness of state institutions, which are not able to provide the legal framework, a productive business environment and the necessary conditions for attraction of investments.

In order to plan government action for integration and strengthening the country's position in global production networks and value chains, it is important to objectively assess the outgoing economic potential and use value-added trade statistics to track the dynamics of trade. It is important for Ukraine to join international initiatives and ensure that national accounts are integrated into international cost-output databases (including the WTO-OECD and the World Input-Output Database).

In modern conditions, from the point of view of economic expediency and technological ability for Ukrainian companies there are realistic strategies for developing segments with the highest share of added value is brand management (in particular intellectual property rights) or control over the consumer/user interface of software products. In the case of industrial production, it is the management of a critical link in the global chain for final production. In the context of a global transition to industry 4.0. and digital economy, the developed

\footnotetext{
${ }^{33}$ Cherkas N. Technological Exports and the Dynamics of Ukraine's Economic Growth // International Economic Policy. - 2006. -No. 4. - pp. 5-28.
} 
information technology sector of Ukraine will serve as a powerful factor in increasing of the efficiency and economic modernization of production. In particular, in order to increase the efficiency of qualified human potential use, a promising direction is the stimulation of entrepreneurship and support for SME initiatives. The tasks of the government include the creation of an effective system of communications between enterprises to facilitate the identification of potential partners; provision of advisory and educational services and facilitating the financing of supplying chains through direct subsidies, or in cooperation with banks and insurance companies, provision of state guarantees and risk sharing. Integration into the technological networks of European industry allows to strengthen the tendency for an improvement in the export-import balance, which is absolutely necessary for strengthening the monetary unit, and it will prevent the emigration of skilled labor.

Affiliation to the global value chains requires a combination of business-friendly factors: an appropriate level of wages, high labor productivity, moderate inflation, a good business environment, a low level of political and economic risk, effective regulatory and tax norms, technology development, and cluster effects, digital data quality, economies of scale. With the aim to stimulate innovative entrepreneurship, it is advisable to use fiscal instruments (special tax incentives, tax credits, or reduced tax rates on innovative products, etc.). The role of the state is primarily to simplify administration as much as possible, to organize the corresponding modern infrastructure and the institutional environment favorable for innovation.

\section{Conclusion}

The rapid development of information technology, accelerating the dynamics of the international movement of goods, services, capital, fragmentation of production, trade and consumption led to the emergence of global production networks and value chains in which individual companies, regions or countries specialize in performing specific operations, and TNCs transfer to outsourcing of a significant part of the processes of products creation or services provision. International competitiveness of companies and countries begins to determinate not only in the volume and technological structure of production or export, but in the creation of a higher share of value added in global chains. The evolution of global networkization concepts is reflected in theories of global production networks that focus on local and global dimensions of institutionalization, corporatization, technologisation and digitalization. 
About half of the exports cost comes from external sources coordinated by regional/global production networks. The fundamental analytical indicator for national economies and their individual sectors is the two-component "index of participation in global value chains". Low rates of participation in global chains are distinctive of developing countries and exporting countries of commodities with low levels of domestic added value, which is confirmed by a sectoral analysis of agriculture, natural resources, business services, electrical and optical equipment.

An effective macroeconomic policy and a favorable business environment create conditions for the international competitiveness of countries and regions and ensure their balanced growth due to the high share of value added. It is associated primarily with the quality of human capital, a strong monetary unit, budgetary discipline and the transparency of the work of state institutions, confirmed by a panel analysis of the impact of key macroeconomic indicators on value added and the global competitiveness of highly developed, Mediterranean and Eastern European countries.

Effective integration of countries in global value chains is ensured by a targeted policy of entry into production networks through the development of clusters, industrial and scientific parks, free economic zones and other innovative competitive spaces, attraction of foreign technology investors, help to the national companies to find trading partners and technologies, improvement of the infrastructure, logistics etc. With the aim to expand and strengthen of own network positions, the priorities are maximization of the absorption potential, stimulation of innovation and development of technological competencies, and compliance with the standardization of goods and business processes. Getting the maximum benefits from participation in global chains, taking into account the balanced development of the country, implies high productivity, fair distribution of opportunities and results of production networks activity, promotion of social modernization and ecologization in the paradigm of sustainable development.

The main directions of the state policy of domestic business integration into global production networks are: implementation of scientific, technological and innovative potential, mobilization of human and intellectual capital, digital transformation of business, international harmonization of legislation, institutional stability, protection of property rights, ensuring of transparency of administration, effectual anti-corruption activities, constructive dialogue and strategic partnership of government and large companies, technological and organizational modernization of production, transport, logistics and social infrastructure, European integration 
development of Ukraine, participation in regional and subregional associations of countries.

\section{References}

1. Antoniuk L., Cherkas N. Macro level analysis of factors contributing to value added: technological changes in European countries // Problems and Perspectives in Management. - 2018. - No. 16(4). - pp. 417-428.

2. Apple's Supplier Responsibility. https://www.apple.com/supplierresponsibility.

3. Baldwin R. The Great Convergence // Harvard University Press. 2016. -329 p.

4. Ceglowski J. Assessing export competitiveness through the lens of value added / The World Economy. - 2017. - No. 40(2). - pp. 275-296.

5. Cherkas N.I. Exchange Rate and Imports' Impact on Ukraine's Export Structure Dynamics (ukr. Vplyv obminnoho kursu ta importu na dynamiku struktury eksportu Ukrainy) / Economics and Forecasting (Ekonomika $i$ prohnozuvannia). - 2013. - No. 2. - pp. 128-139.

6. Cherkas N.I. Technological Exports and the Dynamics of Ukraine's Economic Growth // International Economic Policy. - 2006. - No. 4. - pp. 5-28.

7. Cherkas N.I. Transformational Impact of the Industry 4.0 on Global Production Networks and Value Chains (ukr. Transformatsiinyi vplyv Industrii 4.0 na hlobalni merezhi vyrobnytstva ta lantsiuhy vartosti) / / Economics of Industry (Ekonomika promyslovosti). - 2018. - No. 1(81). - pp. 5-20.

8. Cingolani I., Iapadre L., Tajoli L. International production networks and the world trade structure / International Economics. - 2018. - №153. - P. 11-33.

9. Coe N.M., Yeung H.W.C. Global production networks: Theorizing economic development in an interconnected world // Oxford University Press. - 2015. 266 p.

10. Dicken P., Kelly P.F., Olds K., Wai-Chung Yeung H. Chains and networks, territories and scales: towards a relational framework for analysing the global economy / Global networks. - 2001. - № 1(2). - P. 89-112.

11. Ernst D., Center E.W. Beyond Value Capture-Exploring Innovation Gains from Global Networks / / Megaregionalism 2.0: Trade and Innovation Within Global Networks. -2018. - No. 67. - 55 p.

12. Frohm E., Gunnella V. Sectoral interlinkages in global value chains: spillovers and network effects / / ECB Working Paper. - 2017. - No. 2064. 38 p.

13. Global Value Chain Development Report. International Bank for Reconstruction and Development. The World Bank. -2017. - 190 p.

14. Hernondez V., Pedersen T. Global value chain configuration: A review and research agenda // Business Research Quarterly. - 2017. - No. 20(2). pp. 137-150.

15. Horner R., Nadvi K. Global value chains and the rise of the Global South: unpacking twenty-first century polycentric trade // Global Networks. 2018. - No. 18(2). - pp. 207-237.

16. Johnson R.C., Noguera G. A Portrait of Trade in Value-Added over Four Decades //Review of Economics and Statistics. - 2017. - No. 99(5). pp. 896-911. 
17. Koopman R., Wang Z., Wei S.J. Tracing value-added and double counting in gross exports // The American Economic Review. - 2014. -No. 104(2). pp. 459-494.

18. Nielsen P.B. The puzzle of measuring global value chains - The business statistics perspective / International Economics. - 2018. - No. 153. - pp. 69-79.

19. OECD - WTO Trade in Value-Added (TiVA) initiative. http:/ / www.oecd.org / sti /ind / measuringtradeinvalue-addedanoecdwtojointinitiative.htm.

20. Riaz M.F., Cherkas N., Leitro J. Corruption and Innovation: Mixed Evidences on bidirectional Causality / Journal of Applied Economic Sciences. - 2018. - Vol. XIII, Issue 2(56). - P. 378-384.

21. Shevchuk, V., Atamanchuk, Z., Cherkas, N. Balance of Payments and Remonetization Monetary Effects on the Ukrainian Economy (ukr. Monetarni efekty platizhnoho balansu i remonetyzatsiia ukrainskoi ekonomiky) / / Strategic Priorities (Stratehichni priorytety). - 2007. -No. 3. - pp. 67-75.

22. The World Economic Forum URL: https://www.weforum.org

23. UNCTAD Statistics Data Centre. "International trade". http: / unctadstat.unctad.org.

24. West J. Getting Better Value Out of Global Value Chains // In Asian Century ... on a Knife-edge. Palgrave Macmillan, Singapore. - 2018. - pp. 91-123.

25. WIOD, World Input-Output Database. http://www.wiod.org.

The article was received by the Editorial Board on August 12, 2019. 